\title{
Enthorinal phase precession revisited - single-run analysis of in-vivo grid cell data
}

\author{
Eric T Reifenstein ${ }^{1 *}$, Martin B Stemmler ${ }^{2}$, Andreas VM Herz ${ }^{2}$, Susanne Schreiber ${ }^{1}$ \\ From Twentieth Annual Computational Neuroscience Meeting: CNS*2011 \\ Stockholm, Sweden. 23-28 July 2011
}

When a rat explores its environment, grid cells in the medial entorhinal cortex show increased activity at specific locations that constitute a regular hexagonal grid. As the rat enters and progresses through one of these "grid fields" on a linear track, spikes occur at successively earlier phases in the LFP's theta rhythm. This phenomenon is called phase precession. For rats foraging in two-dimensional environments, however, phase precession has not yet been quantified. Unlike on the linear track, a rat does not repeat the same path over and over again in an open arena; pooling different runs to assess phase precession becomes fraught with difficulty. Instead, we analyze grid cell spike trains recorded by [1] on a run-by-run basis, and do the same also for linear track data (by [2]). Surprisingly, even on the linear track, phase precession during single runs is stronger than the average phase precession in the pooled data. We show that a grid cell spike's theta phase allows one to estimate the animal's position on a linear track to within about $10 \%$ of the size of a typical grid field. The spectrum of grid cell spike trains recorded in a two-dimensional environment reveals a peak that is shifted by approximately $1 \mathrm{~Hz}$ relative to the peak in the LFP theta rhythm, indicative of robust phase precession. We investigate the dependence of spike phase on the radial distance from the grid field center and how phase precession depends on whether the path is transverse or tangential to the grid field, in order to create a model for decoding position in two dimensions from spike phases.

\section{Acknowledgements}

We thank the Moser lab for providing us with the opportunity to analyze their data. This work was supported by the DFG (GRK 1123) and the BMBF (BCCN Berlin, BPCN).

\footnotetext{
* Correspondence: eric.reifenstein@bccn-berlin.de

'Institute for Theoretical Biology, Humboldt-Universität zu Berlin, Berlin, Germany

Full list of author information is available at the end of the article
}

\section{Author details}

'Institute for Theoretical Biology, Humboldt-Universität zu Berlin, Berlin, Germany. ${ }^{2}$ Department Biology II, Ludwig-Maximilians-Universität, PlaneggMartinsried, Germany.

Published: 18 July 2011

\section{References}

1. Sargolini F, Fyhn M, Hafting T, McNaughton BL, Witter MP, Moser MB, Moser El: Conjunctive representation of position, direction, and velocity in entorhinal cortex. Science 2006, 312(5774):758-762.

2. Hafting T, Fyhn M, Bonnevie T, Moser MB, Moser El: Hippocampusindependent phase precession in entorhinal grid cells. Nature 2008, 453:1248-1252.

doi:10.1186/1471-2202-12-S1-P288

Cite this article as: Reifenstein et al:. Enthorinal phase precession revisited - single-run analysis of in-vivo grid cell data. BMC Neuroscience 2011 12(Suppl 1):P288.
Submit your next manuscript to BioMed Central and take full advantage of:

- Convenient online submission

- Thorough peer review

- No space constraints or color figure charges

- Immediate publication on acceptance

- Inclusion in PubMed, CAS, Scopus and Google Scholar

- Research which is freely available for redistribution

Submit your manuscript at www.biomedcentral.com/submit
() Biomed Central
C Biomed Central

C 2011 Reifenstein et al; licensee BioMed Central Ltd. This is an open access article distributed under the terms of the Creative Commons Attribution License (http://creativecommons.org/licenses/by/2.0), which permits unrestricted use, distribution, and reproduction in any medium, provided the original work is properly cited. 